\title{
Preliminary test of encasement of bedding with the high-density fabric for reducing house-dust mites (Acari: Pyrogliphidae)
}

\author{
Yosihiro Natuhara, ${ }^{1)}$ Yasuo Horiuchi, ${ }^{2)}$ Katsuhiko Kidera, ${ }^{3)}$ Kazuko Shino, \\ Hajime Ozaki, ${ }^{4)}$ Jin'ichi Funamoto, ${ }^{4)}$ Shigeko Ueno, ${ }^{5)}$ Akitomo Yoshimura, \\ Takeyuki Sugahara, ${ }^{6)}$ Hiroko Fujitani, ${ }^{6)}$ Toshitaka Gen, ${ }^{6)}$ Mitsuru Saraie, ${ }^{7)}$ \\ Satoshi NAKajima ${ }^{8)}$ and Gen Isshiki ${ }^{8)}$ \\ ") Osaka City Institute of Public Health and Environmental Sciences, \\ Tennoji-ku, Osaka 543, Japan \\ 2) National Sengokuso Hospital, Kaizuka 597, Japan \\ 3) Osaka Municipal Hospital of Kita Citizens' Hospital, Konohana-ku, Osaka 554, Japan \\ 4) Osaka Municipal Hospital of Momoyama Citizens' Hospital, Tennoji-ku, Osaka 543, Japan \\ 5) Osaka Municipal Hospital of Shirokita Citizens' Hospital, Asahi-ku, Osaka 535, Japan \\ 6) Osaka Children's Hospital for Allergic Disease, Kaizuka 597, Japan \\ 7) PL Hospital, Tondabayashi 584, Japan \\ 8) Department of Pediatrics, Osaka City University Medical School, \\ Abeno-ku, Osaka 545, Japan
}

(Received: May 10, 1991)

Key words: house-dust mites, Dermatophagoides, allergy, control, bedding, high-density fabric encasement.

\begin{abstract}
The effect of encasement of bedding with high-density fabric was examined in an effort to prevent infestation with house-dust mites. The study was conducted using the bedding of 22 asthmatic patients. They were divided into 2 groups; floor bedding (futon mattress), blanket and pillow encased with a highdensity fabric were supplied to 1 group, and to the other group bedding was supplied without such encasement. Both of the encased and unencased bedding were wrapped in cotton sheets. Dust was collected from $2 \mathrm{~m}^{2}$ of the upper surface of the cotton sheet before and 4 weeks after the encasement. The mites found were mostly Dermatophagoides. The numbers of both live and dead mites decreased significantly by the encasement. The proportion of futon mattress infested with more than 10 live mites $/ 2 \mathrm{~m}^{2}$ was lower in the encased $(0 / 8)$ than in the unencased bedding $(2 / 14)$ after 4 weeks. That with dead mites was also lower in the encased than in the unencased bedding ( $1 / 8$ and $9 / 14$, respectively).
\end{abstract}

1) 夏原由博：大阪市立環境科学研究所（兵543 大阪 书天王寺区東上町 8-34)

2) 堀内康生：国立療畨所千石荘病院（二597貝塚市 名越 1191)

3) 木寺克彦：大阪市立北市民病院（干554 大阪市此 花区西九条 5-4-8)

4) 志野和子, 尾崎 元, 舟本仁一: 大阪市立桃山市民 病院（豆543 大阪市天王寺区筆ヶ崎町 2-25）
5)上野成子，吉村彰友：大阪市立城北市民病院 (干535大阪市地区商殿 6-14-3)

6) 菅原猛行，藤谷宏子，玄 俊孝：大阪市立少年保養 所 (テ597 貝塚市三ツ松 2499)

7) 更家 充：P L 病院 (千584 富田林市新堂 2182)

9) 中島 理, 一色 玄: 大阪市立大学医学部小児科 （テ545 大阪市阿倍野区旭町 1-4-54） 


\section{INTRODUCTION}

House-dust mites, the most important allergen for asthma, are highly prevalent in domestic bedding (Bronswijk, 1971). The mites mainly live near the surface of mattress stuffing (Mulla et al., 1975). Human skin scales, a major food source for the mites, also accumulate in the stuffing. The mites often move from the stuffing to the surface of the mattress, particularly when overcrowded. Allergens produced there may be inadvertently inhaled by the occupant of the bed. Symptoms of asthma have been reduced by controlling the mites on and in such bedding (WHO, 1988). Control of mites in bedding, therefore, is critical for the alleviation of asthma.

Elimination of house-dust mites from bedding has not been overly successful. Only a small number is eliminated by vacuuming (Mulla et al., 1975) or brushing (Abbott et al., 1981) of the mattresses. Although some methods for killing mites, such as heating the mattress by an electric blanket (Mosbech et al., 1988), have been reported as effective for controlling house-dust mites, the mite population recovers in less than one month (Burr et al., 1980). Thus, many of the reported methods required strict and complicated procedures for long-term mite control (Carswell et al., 1982; Korsgaard, 1983). It is difficult for asthma patients and/or their families to follow such strict procedures.

Since one of the biggest obstruction to the control of mites in bedding is the structural complexity of the stuffing which protects the mites from being removed, the use of a barrier such as plastic to protect the stuffing from outside infestation has been suggested as a possible method of control (Bronswijk, 1974). The plastic covers, however, prevent moisture from diffusing. We examined a new material, a high-density fungicide-impregnated polyester fabric, for the barrier. Data on alleviation of asthmatic symptoms through use of this new material were reported by Horiuchi et al. (1990). The present study evaluates the efficacy of this fabric in the reduction of mite infestation on the surface of floor bedding (futon mattress).

\section{Materials and Methods}

The study was conducted from July 19 to August 24, 1988, with the bedding of 22 patients with mite-allergic asthma who were outpatients at the Osaka Municipal Children's Hospital. The subjects were allocated to 2 groups, each supplied with encased or unencased bedding. Eight sets of futon mattress, blanket and pillow were encased with high-density polyester antimicrobial (Chlorhexidine)-impregnated fabric with very fine pores designed to capture $75 \%$ of particles measuring 0.2-0.4 $\mu \mathrm{m}$ ("Zen'nokku futon cover," manufactured by Ota Shinso, Fukui, Japan). House-dust mites did not pass through this fabric in a laboratory test. Each encased bedding was wrapped in a cotton sheet so as not to be in contact with the bed occupant. Unencased bedding (14 sets) was also wrapped in cotton sheets. The encased bedding was washed every 2 weeks and the cotton sheets once every week. Mites were taken from the floor bedding surfaces $\left(2 \mathrm{~m}^{2}\right)$ with an electric vacuum cleaner (Matsushita Electric Industrial Co., Ltd. MC-A41) for $2 \mathrm{~min}$ just before and 4 weeks after the encasement. A small paper bag $(6 \mathrm{~cm}$ in diameter and $9 \mathrm{~cm}$ in length) was inserted in the tube of the vacuum cleaner. Because the body width of the larval mites is larger than the largest diameter of the pores of the bag $(10 \mu \mathrm{m})$, all mites were caught in it. Mites were isolated from the entire quantity of collected dust by the wet-sieving method (Natuhara, 1989). Mites were recorded as 'live' or 'dead' as an estimate of whether the mites were alive or dead at the time of sampling. 'Live' mites possessed a filled body and all legs, whereas 'dead' mites possessed a shrunken body and/or lacked some leg segments.

\section{Results}

The mites found were mostly Pyroglyphidae and including $D$. pteronyssinus (Trouessart), D. farinae Hughes and a few Euroglyphus maynei (Cooreman). These three pyroglyphid mite species have common antigens; therefore, the total number of individuals was used for subsequent analyses. 


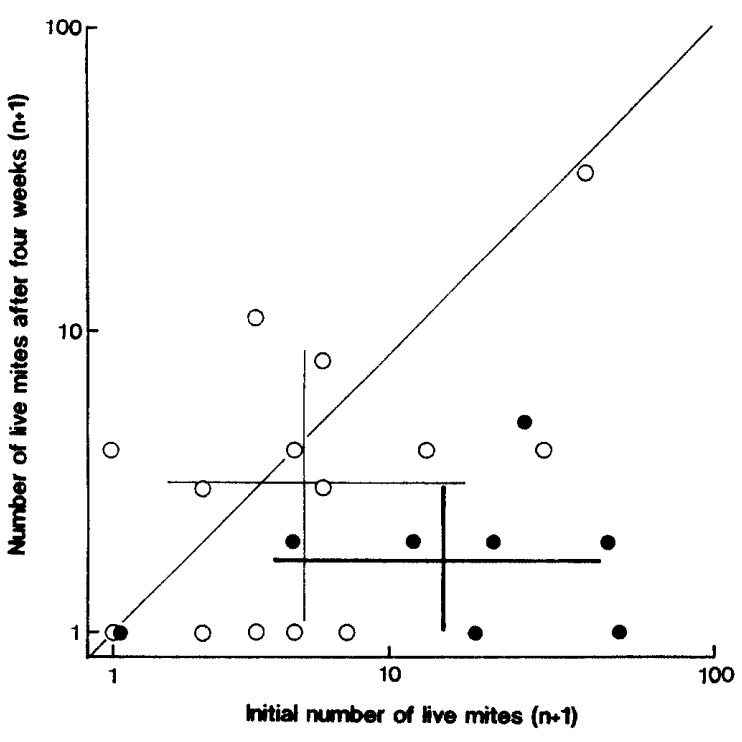

Fig. 1 Changes in the number of live mites on encased ( $)$ and unencased $(O)$ futon mattresses before and 4 weeks after the encasement.

Heavy horizontal and vertical lines indicate the ranges of standard deviation of the mean number of mites before and 4 weeks after, respectively, for the encased futon mattress; thin lines for the unencased one. Intersects of these lines represent mean values. The solid line with a slope of 1 indicates that numbers of mites before and 4 weeks after the encasement were the same.

The weight of sample dust from the encased futon mattresses was $65.4 \pm 54.2 \mathrm{mg}$ (mean \pm standard deviation) before the encasement and $16.5 \pm 11.9 \mathrm{mg} 4$ weeks after the encasement; dust weight from the unencased futon mattresses was $66.4 \pm 70.1 \mathrm{mg}$ and $109.0 \pm 75.3 \mathrm{mg}$, respectively.

Figure 1 shows the change of the numbers of live mites on the encased and unencased futon mattresses during 4 weeks. In the figure, it is shown that the number of mites decreased or remained constant during the test period in all but 4 unencased futon mattresses (open circles). The geometric means (and ranges of standard deviation) of mite numbers on the encased futon mattresses decreased from $12.4(3.4-44.7)$ to $1.7(0$ $3.0)$ per $2 \mathrm{~m}^{2}$ of mattress. In contrast, mite numbers on the unencased futon mattresses remained unchanged, being from 4.4 (1.5$12.6)$ to $3.1(1.1-8.9)$. Furthermore, the

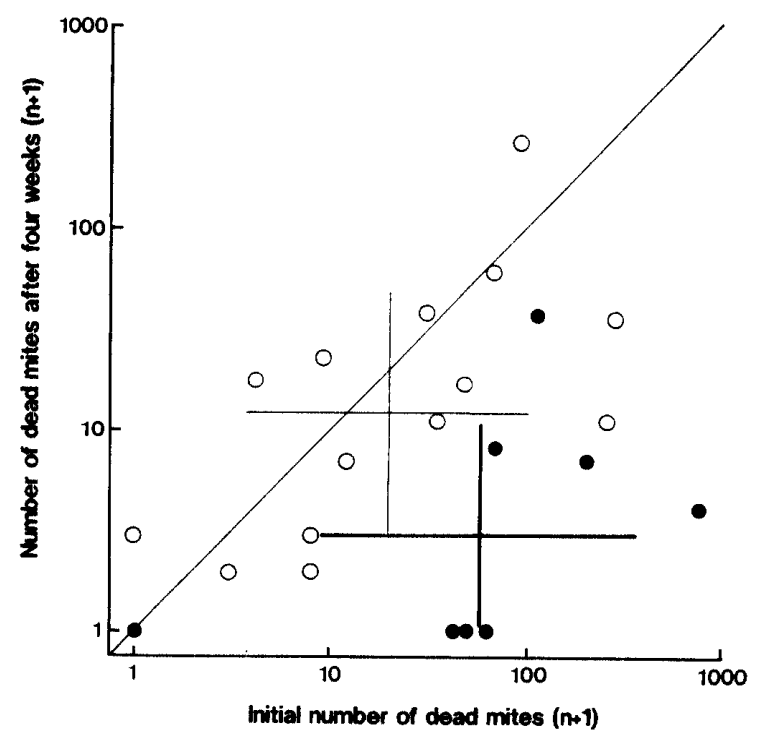

Fig. 2 Changes in the number of dead mites during the test period.

For details, see caption of Fig. 1.

proportion of heavily infested futon mattresses $\left(>10\right.$ live mites $/ 2 \mathrm{~m}^{2}$ ) was smaller in the encased $(0 / 8)$ than in the unencased ones $(2 / 14)$ after 4 weeks.

The number of dead mites decreased in all of the encased futon mattress except one on which no mites had been found before the encasement (Fig. 2). Mean numbers (range of standard deviation) of dead mites decreased from 58.7 (8.9-389), to 3.1 (011.7 ) by encasing during 4 weeks. In five out of 14 unencased futon mattresses, the number of mites increased after 4 weeks. Mean number of mites decreased slightly from $20.0(3.8-104)$ to $13.1(3.2-54.8)$ in the unencased group. The proportion of heavily infested futon mattresses with more than 10 dead mites $/ 2 \mathrm{~m}^{2}$ was smaller in the encased $(1 / 8)$ than unencased ones $(9 / 14)$. Significant difference between the numbers of mites before and 4 weeks after the encasement was seen for both live and dead mites by Wilcoxon's signed-ranks test.

\section{Discussion}

We found that encased bedding with highdensity fabric prevented mite infestation of the futon mattress for at least 4 weeks. The proportion of heavily infested futon mattresses to the total number of futon mattresses 
was lower in the encased group 4 weeks after the encasement, although the difference in mean mite numbers was not significant between the encased and unencased groups. Reduction of heavy mite infestation of mattresses is important for asthmatic patients, because mite infestation above a certain level introduces asthma (Korsgaard, 1982); according to Wharton (1976), a sanitary standard is 12 mites $/ 0.5 \mathrm{~m}^{2}$. Suppression of the mite density to below Wharton's standard was accomplished in seven mattresses out of eight. Average symptom score of patients using the bedding encased with the new fabric decreased until 6 weeks after the encasement, then slightly increased at 10th week (Horiuchi et al., 1990).

Some mites found on the encased futon mattresses probably came from the floor of the bedroom or from the clothes of patients. Immigration of a few mites is unavoidable, but these mites are removed when the cotton sheets and bedding encased with high-density fabric are washed.

Mulla et al. (1975) successfully controlled the number of Dermatophagoides on mattresses by encasing the mattresses with plastic for 6 months. The plastic covers, however, prevent moisture from diffusing, and would lead to fungus growth in futon mattresses in Japan. The high-density fabric is superior to plastic in this respect.

Although a fungicide was applied to the new fabric, we did not examine its effect on house-dust mites. Bronswijk et al. (1987) reported suppression of house-dust mites by the fungicide Natamycin ${ }^{\circledR}$. The combination of the high-density fabric and a fungicide might have provided the good effect for the mite control in the present study.

\section{ACKnowlengements}

We thank Dr. C. Imai of Osaka City Institute of Public Health and Environmental Sciences for reviewing the manuscript. We should also like to thank Dr. A. Yamada and Dr. S. Morita of the Institute for their advice and encouragement during the study.

\section{REFERENGES}

Abbott, J., J. Cameron and B. Taylor (1981):
House dust mite counts in different types of mattresses, sheepskins and carpets, and a comparison of brushing and vacuuming collection methods. Clin. Allergy, 11: 589-595.

Bronswijk, J. E. M. H. van (1971): Dermatophagoides pteronyssinus (Trouessart, 1897) in mattress and floor dust in a temperate climate (Acari: Pyroglyphidae). J. Med. Entomol., 10: $63-70$.

Bronswijk, J. E. M. H. van (1974) : Colonisation and its prevention on house floors and in mattresses with Dermatophagoides pteronyssinus (Acari: Sarcoptiformes) in a center for asthmatic children. Entomol. Exp. Appl., 17: 199-203.

Bronswijk, J. E. M. H. van, J. W. F. Reumer and R. Pickard (1987): Effects of fungicide treatment and vacuuming on Pyroglyphid mites and their allergens in mattress dust. Exp. Appl. Acarol., 3: 271-278.

Burr, M. L., E. Naele, B. V: Dean and E. R. Verrier-Jones (1980): Effect of a change to mite-free bedding on children with mite-sensitive asthma: a controlled trial. Thorax, 35: 513514.

Carswell, F., D. W. Robinson, J. Oliver, J. Clark, P. Robinson and J. Wadsworth (1982): House dust mites in Bristol. Clin. Allergy, 12: 533545.

Horiuchi, Y., K. Kidera, K. Shino, T. Sugahara. H. Fujitani, M. Saraie, S. Nakajima, G. Isshiki and Y. Natuhara (1990): Effect of preventive measures on children with mite-sensitive asthma. J. Pediatr. Allergy, 4: 15-21 (in Japanese with English summary).

Korsgaard, J. (1982): Preventive measures in house-dust allergy. Am. Rev. Respir. Dis., 125 : 80-84.

Korsgaard, J. (1983): Preventive measures in mite asthma. Allergy, 38: 93-102.

Mosbech, H., J. Korsgaard and P. Lind (1988) : Control of house dust mites by electrical heating blankets. J. Allergy Clin. Immunol., 81: 706710.

Mulla, M. S., J. R. Harkrider, S. P. Galant and L. Amin (1975): Some house-dust control measures and abundance of Dermatophagoides mites in southern California (Acari: Pyroglyphidae). J. Med. Entomol., 12: 5-9.

Natuhara, Y. (1989): A new wet sieving method for isolating house dust mites. Jpn. J. Sanit. Zool., 40: 333-336.

Wharton, G. W. (1976): House dust mites. J. Med. Entomol., 12: 577-621.

WHO (1988): Dust mite allergens and asthma: a world-wide problem. Bull. W. H. O., 66: $769-780$. 
摘要

高密度織物製布団カバーの

$$
\text { ダ二増殖予防効果 }
$$

高密度織物を誛具カバーとして使用した場合にダニ 污染を防ぐ効果の試験を行った，試験は22人の喘息患 児の寝具を対象とした。寝具を 2 群にわけ，一群の敷 布団，掛け布団，枕を高密度織物製のカバーで抢㧤い 着用群とし，もう一群はカバーでおおおず非着用群と
した。演具はさらに供試カバーの上から木綿のシーツ でおおおい，同じシーツをコントロールにも使用した。 ほこりはカバー着用前上着用 4 週間後に木綿シーツの 上面 $2 \mathrm{~m}^{2}$ から採取した。検出されたダニは主にヒョウ ヒダニ属であった．カバー使用の結果，ダ二個体数は 生死体とも有意に減少した. 着用 4 週間後に多数のダ 二に污染されていた敷布団（ダ二生体 10 個体以上 $/ 2$ $\left.\mathrm{m}^{2}\right)$ はカバー着用群 $(0 / 8)$ で非着用群 $(2 / 14)$ より少 なかった．多数のダ二死体による污染も着用群は非着 用群よりより少なかった $(1 / 8$ および $9 / 14)$. 